\title{
The Development of Textbook Learning Media Based on Local Wisdom of North Sumatera
}

\author{
Uyuni Widiastuti ${ }^{1}$, Adina S Sembiring ${ }^{2}$, Mukhlis ${ }^{3}$, Lamhot B Sihombing ${ }^{4}$, Theodora \\ Sinaga ${ }^{5}$, Purbatua Manurung ${ }^{6}$ \\ 1,2,3,4,5 Universitas Negeri Medan, Indonesia \\ ${ }^{6}$ Universitas Islam Negeri Sumtera Utara, Indonesia \\ uyunifbs@gmail.co.id
}

Abstract

The textbook developed in this study is adapted to the 2013 curriculum applicable in SMA, namely the material in class $X$. The material is adapted to the local wisdom of North Sumatra, especially in traditional Karo songs and music. This textbook describes the traditional Karo music in the form of a kulcapi drum ensemble whose instruments consist of kulcapi, keteng-keteng and bowl. This textbook is equipped with techniques in playing the kulcapi drum on the song Piso Surit and Terang Bulan. The existence of this textbook is very helpful for Cultural Arts teachers in teaching music based on local wisdom of North Sumatera.
Keywords

development; textbooks; local wisdom; North Sumatera

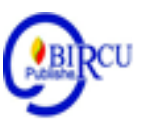

\section{Introduction}

Art education is a conscious effort to pass on or transmit the ability to make art as a manifestation of the transformation from generation to generation carried out by artists or art actors to anyone who is called to become a prospective artist. Art education itself aims to develop students' aesthetic experiences so that they have a sense of sensitivity and care for something beautiful, easy, careful to receive external stimuli, their conscience can easily be touched so that they become sensitive humans. In fact, cultural transformation through art education has been going on since the beginning of human civilization until now. Plato once said that "art education should be the basis for education", art education should be the basic of education. The art of music becomes an inseparable part of dance performance, which has a role as a dancer's accompaniment in performing dance moves. (Febrianto, 2020).

Arts education starts from the lowest level of education (TK / PAUD), elementary (SD) secondary (SMP / SMA) to the highest level (Higher Education). In general, the material in art education is the same at every level, only the level of depth is different which is adjusted to each level. The realm of art education consists of two,appreciation(relating to theory) and expression (relating to practice). These two domains must be implemented in students in order to provide students with artistic experiences.

Art education at the secondary level, especially high school, is in the subject of Cultural Arts which includes four fields of art, namely music, dance, fine arts and theater. The four arts fields must be taught by a teacher in the Cultural Arts subject even though the teacher's educational background is only in one art field. Therefore, the Cultural Arts teacher must broaden his horizons in order to provide other art material to students.

Observations that have been made with the teachers who teaches Cultural Arts that the material taught to students is only obtained from books available in schools and the use 
of standard learning media (youtube). This results in less than optimal learning because the material from both sources is very monotonous and does not vary. Through this research, learning media will be made in the form of textbooks so that it helps the Cultural Arts teachers teach material on the art of music. Currently, the material provided is still national in nature (the same as in other regions in Indonesia) and does not show local wisdom where the school is located.

The development of textbooks in this study was adapted to the 2013 curriculum applicable in high school, namely the material in class X. The material was adapted to the local wisdom of North Sumatra, especially in traditional Karo songs and music. All of these music learning media also refer to the Basic Competencies in the 2013 curriculum, namely: (1) Presentation of Music Works; (2) Making your own musical works complete with writing scores; (3) Performing his own work; and (4) Music Criticism. Music learning media will later be used by high school level cultural arts teachers. This research is very important to do because the presence of appropriate learning media can make learning more interesting and meaningful and determine the quality of learning.

Learning is an assistance provided by educators so that the process of acquiring knowledge and knowledge, mastery, proficiency and character and the formation of attitudes and self-confidence in students can occur. In other words, learning is a process to help students learn well. According to Komalasari (2013) Learning is a system or process of learning that learners are planned, implemented and evaluated systematically so that learners can achieve learning goals effectively and efficiently. This is confirmed by Sanjaya (2011) that learning is a complex system whose success can be seen from two aspects, namely the product aspect and the process aspect. Learning success seen from the product side is the success of students regarding the results obtained by ignoring the learning process. The success of learning in terms of results is easy to see and the criteria are determined, but this can reduce the meaning of the learning process as a process that contains educational values. Gagne's view (in Anni, et al, 2007) suggests that learning is a collection of individual processes, which transform stimuli from a person's environment into a number of information, which in turn can lead to learning outcomes in the form of long-term memories. however this can reduce the meaning of the learning process as a process that contains educational values. Gagne's view (in Anni, et al, 2007) suggests that learning is a collection of individual processes, which transform stimuli from a person's environment into a number of information, which in turn can lead to learning outcomes in the form of long-term memories. however this can reduce the meaning of the learning process as a process that contains educational values. Gagne's view (in Anni, et al, 2007) suggests that learning is a collection of individual processes, which transform stimuli from a person's environment into a number of information, which in turn can lead to learning outcomes in the form of long-term memories.

Learning media is a communication tool between a message source (a source) and a message receiver (a receiver), such as television, films, diagrams, printed materials, and others. Examples of these media can be considered as learning media if they carry messages in order to achieve learning objectives. This shows a relationship between media and messages and methods. According to Gagne in Rusman (2012) media are various types of components in the student environment that can provide stimulation for learning. Furthermore, Djamarah and Zain (2010) revealed that learning media are any tools that can be used as a channel for messages to achieve learning objectives.

Learning media are classified based on their nature, range and use techniques: a. By its nature, the media can be divided into: 
1. Auditive media, namely media that can only be heard or media that have sound elements

2. Visual media, which is only visible media, does not contain sound elements

3. Audiovisual media, which is a type of media that in addition to containing sound elements also contains visible image elements.

b. From its reachability, the media can also be divided into:

1. Media that has broad and simultaneous coverage

2. Media that has limited coverage by time and space

c. From the way or technique of use, the media can be divided into:

1. Projected media

2. Media that is not projected

Teaching materials are subject matter that will be delivered by educators to students in the form of written and unwritten materials. Therefore educators must be able to compile the teaching materials that will be used in the learning they teach (Widiastuti, 2019). Textbooks are textbooks in certain fields of study, which are standard books, compiled by experts in certain fields with instructional aims and objectives, equipped with teaching facilities that are compatible and easily understood by the wearer in schools. and universities so that they can support a teaching program. Textbooks are textbooks in a particular field of study which are standard books compiled by experts in their fields for instructional purposes and are equipped with teaching facilities that are compatible and easily understood by school users and in higher education so that it can support a teaching program. Based on the description, textbooks are used for certain subjects. The use of textbooks is based on learning objectives that refer to the curriculum. In addition to using textbooks, teachers can use tools or techniques that are in accordance with the objectives that have been made previously. The use of combining textbooks, techniques and other means is intended to facilitate textbook users, especially students in understanding the material, Tarigan and Tarigan (2009).

in general, distinguishes books into 4 types, namely:

a. Source book is a book that is usually used as a reference, reference, and source for certain scientific studies, usually containing a complete scientific study.

b. Reading books is a book that only functions for reading material, for example stories, legends, novels, and so on.

c. Handbook is a book that can be used as a guide for teachers or teachers in carrying out the teaching process.

d. Textbooks is a book prepared for the learning process, and contains materials or subject matter to be taught.

Local wisdom consists of two domains, namely wisdom and local. Wisdom means wisdom and local means local. Another understanding of local wisdom is a part of community culture that cannot be separated from the language of the community. Local wisdom is usually passed on by word of mouth. Local wisdom exists in folklore, songs, proverbs, music, folk games, and so on. Local wisdom is knowledge obtained by the presence of certain local people through a collection of experiences in expression and integration into an understanding of the culture and natural conditions of a place.

According to Sibarani (2012) the notion of local wisdom is a form of native knowledge in society that comes from the noble values of local culture to regulate the order of community life or it is said that local wisdom. Furthermore, Warigan (2012) states that the values that exist in local wisdom in Indonesia have been proven to contribute to the progress of society. Another opinion suggests that local wisdom is often called local wisdom which can be understood as human efforts by using their intellect to act and behave towards an object or event that occurs in a certain space, Ridwan (2007). 


\section{Research Method}

This study uses a qualitative research approach, which is a research process that aims to understand a human problem based on the preparation of a complex and comprehensive picture according to the detailed views of the informants and carried out in the middle of a natural setting. According to Bogdan in Basrowi and Suwandi (2008), qualitative research is a research procedure that produces descriptive data in the form of speech or writing and the behavior of the people being observed.

Sources of data in this study are: (1) Primary data is data obtained directly from informants, namely cultural arts teachers, especially music teachers; (2) Secondary data is data obtained from other sources, such as: books, recordings, class X cultural arts syllabus or from other sources in order to support research data.

Data collection techniques in this study were: (1) Observation, carried out to confirm the collected data by observing directly (2) Interview, used for communication with related parties such as Cultural Arts teachers; (3) Documentation, is carried out to support the research process, where not all things can be known. Therefore it can be done by taking notes, transirp, books, recordings and so on

According to Miles \& Huberman in Sugiono (2014), the analysis consists of three activity lines, namely; (1) Data reduction, defined as the selection, concentration of attention, simplification, abstracting and transformation of data that appear in the field. During data collection, there were further data reduction stages, such as: summarizing, coding, exploring themes, creating clusters, creating partitions, creating memos. This data reduction continues until the field research takes place, until the final research report is compiled; (2) Better data presentation is a major means of qualitative analysis which includes matrices, graphs, networks and charts. Everything is structured to combine information in an unified form, so that you can see what happened and determine whether to draw the correct conclusion;

\section{Discussion}

This study describes the textbook design compiled by the researcher for use in learning Cultural Arts on traditional Karo music material. The textbook designed by the researcher is a book about the technique of playing the kulcapi drum (keteng-keteng, kulcapi, and bowl) in the song.Piso Surit and the Light of the Moon. The textbook is designed to be very helpful for high school level cultural arts teachers in providing material for the practice of traditional karo music which will be described below.

One of the musical ensembles that still exist in the Karo community is the gendang kulcapi ensemble. There are three instruments in this ensemble, the kulcapi which acts as the carrier of the melody, the keteng-keteng which acts as a rhythm carrier, and the mbentar bowl which acts as the guardian of the tempo. This ensemble was often used for ritual purposes including the erpangir kulau ritual, the begu house ritual, and the ndilo wari udan ritual. One of the musical figures in the drum Kulcapi ensemble who often uses this ensemble in rituals is Alm. Djasa Tarigan. He can be called as one of the kulcapi figures who is still highly respected because his playing techniques hit the hearts of the Karo people and Karo artists.

Over time, the drum kulcapi ensemble eventually changed as needed. The context of the event, even the taste of the Kulcapi ensemble audience. Currently the kulcapi ensemble has been played in various cultural events, rituals, and the realm of the performing arts. 


\subsection{The Existence of the Kulcapi Ensemble in the Karo Community}

Compared to the sarunei gendang ensemble, the kulcapi drum ensemble seems to be more accepted by all ages in the social life of the Karo people. This is because in the last few years the sarunei drum has become more synonymous with the traditional death ceremony, which has resulted in minimal interest especially for young people. This of course needs to be straightened out but it needs a more special discussion.

Currently, especially the kulcapi instrument, the enthusiasts are quite evenly distributed in every village, church, and even groups of young people who do not only have musical backgrounds. In every church, for example, almost there are kulcapi players who want to learn and some are even at the expert stage. They learn automatically according to the needs and demands around them. Seeing archipelago arts which are oral traditions, this is indeed a common thing, but in the realm of education, it is necessary for academics to write a training method especially the kulcapi ensemble so that it will make it easier for everyone to learn with traditional standards that have been passed down from generation to generation. Seeing this, the writer feels the need to make a simple book related to the understanding and simple techniques of the Kulcapi drum ensemble.

\subsection{Description of the Gendang Kulcapi Ensemble a. Kulcapi}

Kulcapi is the only stringed instrument in the Karo community arts. This is supported by the absence of research or sources from the artists who state that there are other stringed instruments besides kulcapi. Kulcapi musical instrument has only two strings and five frets. Kulcapi musical instruments can be used as carriers of melodies and become chords at the same time. Historically kulcapi strings were once made from the finest roots of the palm tree. This root is dried before being used as snar kulcapi. You can imagine the sound of kulcapi in the past, of course, between the low range to slightly approaching the midle. Kulcapi games can only cover one to two octaves pitch distance in playing a song. This is due to the limitation of the kulcapi fret.

\section{Kulcapi Playing Technique}

Just like other stringed instruments, playing kulcapi one of the most important techniques is the picking technique, but in the kulcapi game there are several important techniques that must be mastered including picking techniques or in terms of kulcapi music it is called dilah technique, rengget technique, and tounggum technique.

Dilah technique is the first priority in mastering the kulcapi game, in this technique kulcapi players must master the ups and downs of the passages with several rhythm variations. The technique of rengget is also considered very important because it is an element of Karo's musical identity. If this technique is not mastered, usually the kulcapi player is considered imperfect or unable to play kulcapi. The tounggum technique is a resonance hole playing technique to produce different sound effects. This technique is produced using the stomach. In this study the author will focus on the techniques of playing kulcapi in the song Piso Surit and Terang Bulan. 


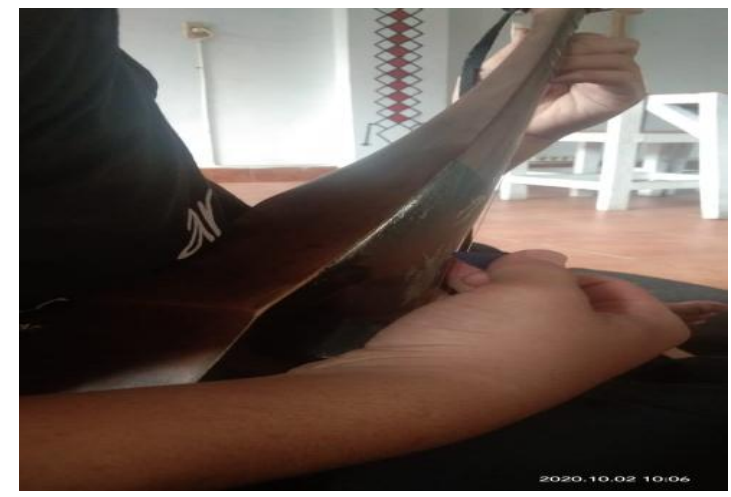

Figure 1. Dilah Technique

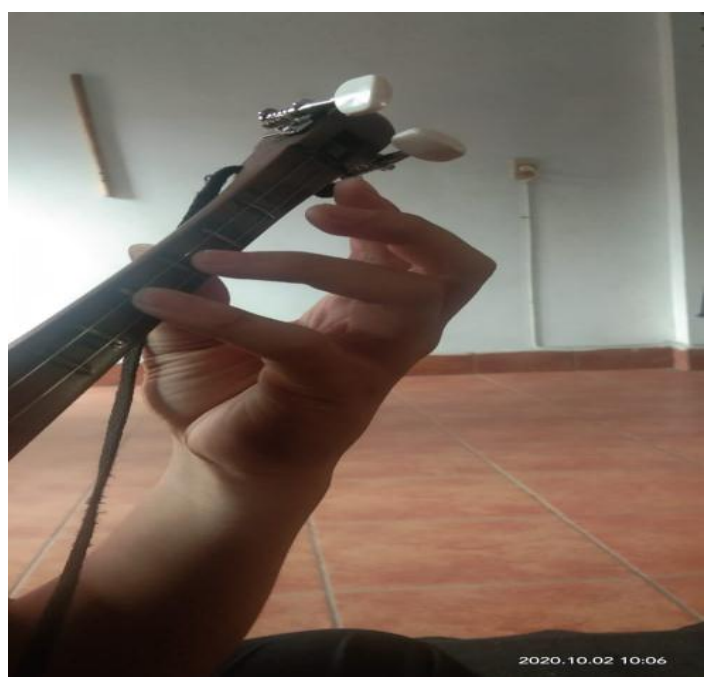

Figure 2. Rengget Technique

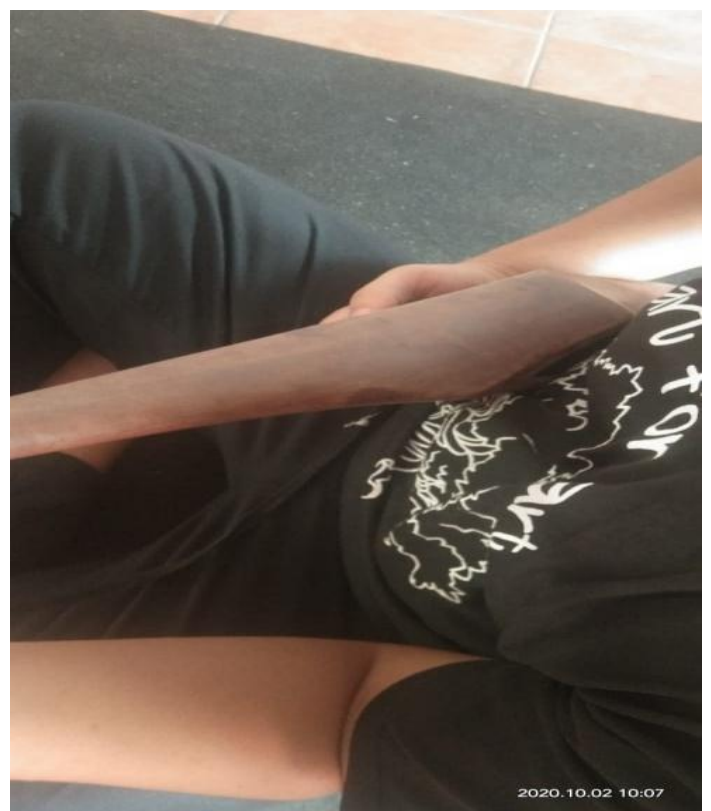

Figure 3. Tounggum Technique 


\section{Kulcapi Game Techniques in the Piso Surit Song}

Basically, the technique of playing kulcapi is generally the same as previously described, but for the position of the fingers it is a little different because of the scale instrument being played. In the song Piso Surit, the position of the wrists is closer to the neck of the kulcapi because the tones are around the neck of the kulcapi. In order to produce the rengget a little easier because the pitch distance in the kulcapi is very close. This of course makes it easier for kulcapi players to produce battens.

\section{Kulcapi Game Techniques in Terang Bulan Song}

In the song Terang Bulan, the position of the wrists is further away from the neck of the kulcapi. This is because the pitch distance in the moonlit song is wider than in the piso surit song. For people who are just learning kulcapi, it is usually more complicated to produce a rengget in a tonal distance such as a moonlit song. Both songs use the tounggum technique depending on the needs or tastes of the kulcapi players themselves. Especially for this technique it is not an obligation for every kulcapi player but it remains an important part, especially in acoustic playing. So in general, every kulcapi player is actually expected to be able to master the three basic techniques in the kulcapi game, namely the Dilah technique, the rengget technique, and the tounggum technique.

\section{b. Keteng-Keteng}

Kick-offis one of the traditional Karo ethnic musical instruments made of bamboo. Keteng-keteng musical instrument is a combination of three instruments, namely gung, penganak and drums. The three instruments are contained in a single bamboo blade which is played by a musician. In a keteng-keteng music instrument there are two ropes and three ropes and has a hole that produces a gung sound.

\section{Playing Tap Techniques}

Similar to other percussion instrument playing techniques, keteng-keteng musical instruments are also played by being hit. However, the grip strength on the stick should not be too strong or too loose. There are two important techniques in playing sticks on a keteng musical instrument, namely by hitting as usual and hitting while pressing to produce timbre pliers and checks. The right hand produces pliers and the left tangin makes a check sound by hitting while pressing.

The research focuses more on the technique of playing the song Terang Bulan and Piso Surit, therefore it is necessary to understand the types of rhythms in Karo art in general, which there are three major types of rhythm, namely the simelungen rayat rhythm, the odak-odak rhythm, and the patam-patam rhythm. The song Terang Bulan and Piso Surit uses the odak-odak rhythm.

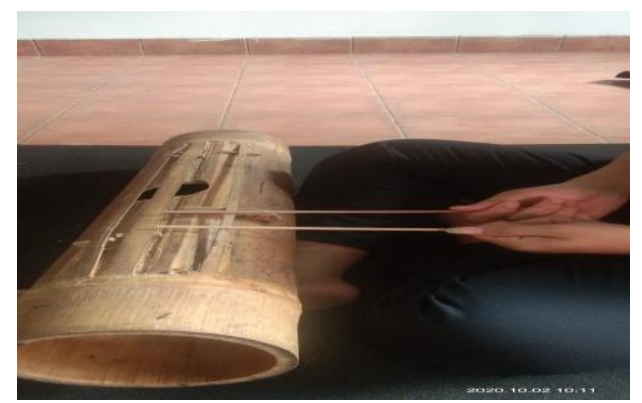

Figure 4. Pliers Technique 


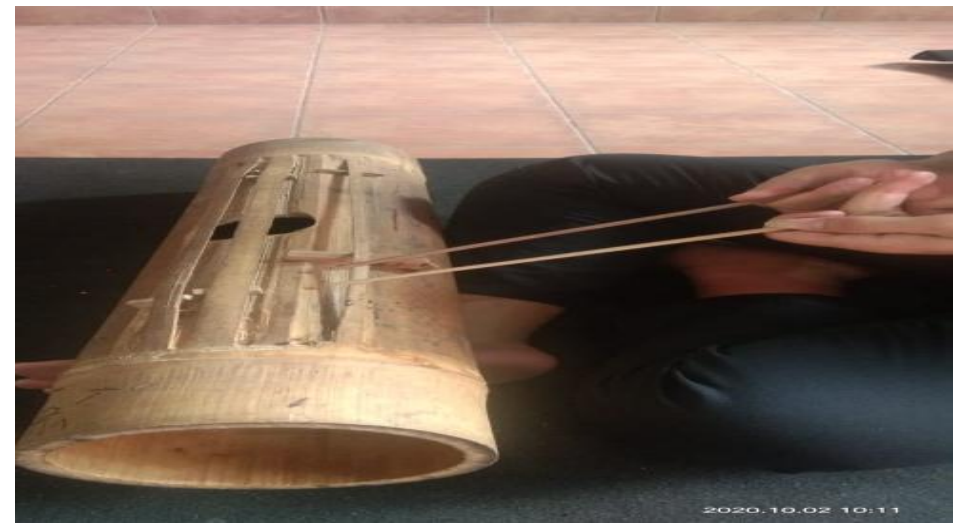

Figure 5. Check Techniques

\section{c. Bowl}

Bowl or in Indonesian is a bowl. The bowl is used to guard the metronome. There has been no research on why the bowl is included in the Kulcapi drum ensemble because the sound function can already be represented in the drum. Judging from the function of the bowl in Karo culture, it is possible that in the past, the bowl was used not only for the sake of sound but could also be used for the importance of placing offerings (belo cawir) when holding rituals. In a bowl game it also looks the simplest because it is played only a few taps.

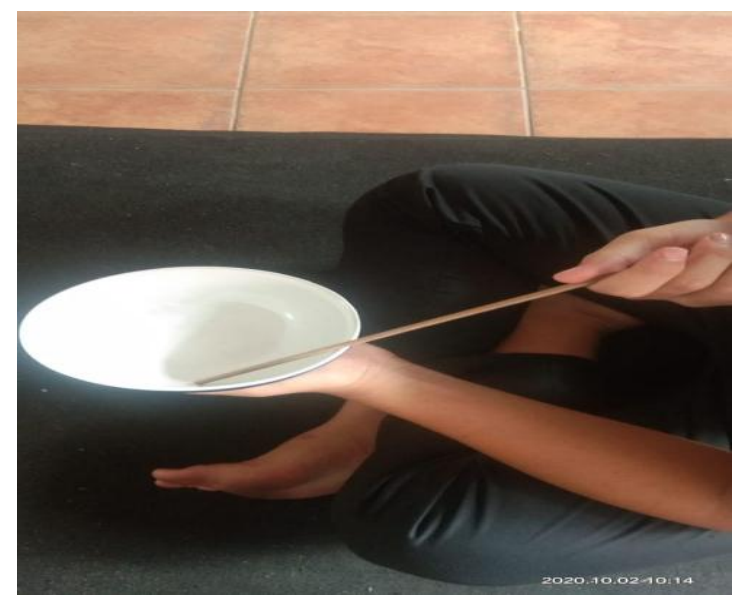

Figure 6. Moment Bowl

\section{Conclusion}

In accordance with the title "Development of Textbook Learning Media Based on North Sumatra Local Wisdom", the textbooks developed in this study are adapted to the 2013 curriculum applicable in SMA, namely the material in class X. The material is adapted to the local wisdom of North Sumatra, especially in Karo traditional songs and music. This textbook describes the traditional Karo music in the form of a kulcapi drum ensemble whose instruments consist of kulcapi, keteng-keteng and bowl. This textbook is equipped with techniques in playing the kulcapi drum on the song Piso Surit and Terang Bulan. The existence of this textbook is very helpful for Cultural Arts teachers in teaching music based on local wisdom of North Sumatra. 


\section{References}

Anni,dkk, 2007, Psikolgi Belajar, Semarang: UPT Unnes Press.

Basrowi, Suwandi, 2008, Memahami Penelitian Kualitatif, Jakarta: Rineka Cipta

Dzamara, Zain.2010. Strategi Belajar Mengajar. Jakarta: Rineka Cipta, Edisi Revisi.

Fatimah, dkk, 2019, Development of Smart Content Model-Based Augmented Reality to Support Smart Learning, Journal of Science Learning, v2 n2 p65-70 2019

Febrianto, E.G., Djono, and Sudiyanto. (2020). The Existence of Jaranan Pogogan in Sugihwaras, Prambon, Nganjuk, Indonesia. Budapest International Research and Critics in Linguistics and Education (BirLE) Journal Vol 3 (2): 773-776.

Hadi, Rizali, dkk, 2017, Economic Learning Media Development Based on Local Locality, International Journal of Higher Education, v6 n3 p188-194.

Jung, Kiho; Otaka, Yuki, 2019, The Introduction of a Thin-Bending Wood Horn Speaker as Multipurpose Teaching Material in Japanese Junior High School Technology Classes World Journal of Education, v9 n6 p57-64.

Liliarti, dkk, 2018, Improving the Competence of Diagrammatic and Argumentative Representation in Physics through Android-Based Mobile Learning Application

International Journal of Instruction, v11 n3 p107-122 Jul.

Miles \&Huberman, 1996, Analisis Data Kualitatif, Jakarta: Universitas Indonesia Press

Rayandra, Asyar. 2012. Kreatif Mengembangkan Media Pembelajran. Jakarta: Gaung Persada Press.

Rusman, dkk, 2012. Pembelajaran berbasis Teknologi Informasi dan Komunikasi : Jakarta: PT Grafindo Persada

Sibarani, Robet, 2012, Kearifan Lokal : Hakikat, Peran dan Metode Tradisi Lisan, Jakarta: Asosiasi tradisi lisan (ATL).

Sugiono, 2014. Metode Penelitian Pendidikan Kuantitaif dan Kualitatif, R\&D, Bandung: Alfabeta.

Tarigan, Henry Guntur dan Djago Tarigan. 2009. Telaah Buku Teks Bahasa Indonesia. Bandung: Penerbit Angkasa.

Warigan, 2012, Pengembangan karakter berbasis kearifan lokal hamemayu hayuning bawana (identifiksdi nilai-nilai karakter berbasis budaya, Yogyakarta: Universitas Negeri Yogyakarta

Wahyuni, S, 2013. Keberagaman Dan Makna Nilai Kerifan Lokal Sebagai Sumber Inspirasi Pembelajaran Seni Budaya Yang Berkarakter. Madiun.

Widiastuti, U., et al. (2019). Development of Traditional Harmony-Based Teaching Materials Based on HOTS to Improve Student Musicality of Music Education Program at Language and Art Faculty at State University of Medan (UNIMED). Budapest International Research and Critics in Linguistics and Education (BirLE) Journal Vol 2 (4): 227-238. 